\title{
Predominance of herpes simplex virus type 1 from patients with genital herpes in Nova Scotia
}

\author{
Kevin R Forward MD FRCPC, Spencer HS Lee PhD
}

KR Forward, SHS Lee. Predominance of herpes simplex virus type 1 from patients with genital herpes in Nova Scotia. Can J Infect Dis 2003;14(2):94-96.

The epidemiology of genital herpes is changing with evidence to suggest an increasing incidence of herpes simplex virus type 1 (HSV-1) infections. The results of 6529 HSV genital cultures taken between April 1998 and December 2001 were reviewed. Overall, HSV-1 was recovered more often than HSV-2; 1213 versus 1045. This trend was particularly striking in young women 30 years of age or less, in whom $70.8 \%$ of isolates were HSV-1. In men of the same age range, $45 \%$ of isolates were HSV-1. The proportion of women with HSV-1 declined from $73.7 \%$ in those younger than 31 years of age to $4.5 \%$ in those older than 60 years of age.

These observations have important implications. The decline in the relative proportion of HSV-1 isolates from young adults may be the result of changing sexual practices, changing susceptibility or increased exposure to HSV-1 during vaginal intercourse. In this setting HSV-2 vaccines may be less likely to produce the desired reduction in the overall prevalence of genital herpes infections.

Key Words: Genital herpes; Herpes simplex virus type-1

\section{Prédominance de l'herpès simplex virus type I chez des patients souffrant d'herpès génital en Nouvelle-Écosse}

\begin{abstract}
RÉSUMÉ : L'épidémiologie de l'herpès génital évolue et les observations indiquent une augmentation de l'incidence d'infections à herpès simplex virus type I (HSV 1). Les résultats de 6529 cultures génitales de HSV prélevées entre les mois d'avril 1998 et décembre 2001 ont été passés en revue. Dans l'ensemble, le HSV 1 a été décelé plus souvent que le HSV 2; soit 1213 cultures contre 1045 .

Cette tendance était particulièrement frappante chez les jeunes femmes de moins de 30 ans chez lesquelles 70,8\% des isolats étaient positifs pour le HSV 1 par rapport à 45 \% pour les hommes du même groupe d'âge. La proportion de femmes positives pour le HSV 1 est passée de $73,7 \%$ chez les femmes de moins de 31 ans à 4,5\% chez celles qui avaient plus de 60 ans.

Ces observations ont une incidence importante. En effet, la baisse de la proportion relative d'isolats de HSV 1 décelés chez de jeunes adultes peut résulter d'une modification des pratiques sexuelles, d'un changement de la susceptibilité ou d'une exposition accrue au HSV 1 durant les rapports sexuels vaginaux. Dans ces circonstances, les vaccins anti HSV 2 seraient moins susceptibles de produire la réduction souhaitée de la prévalence globale des infections herpétiques génitales.
\end{abstract}

$\mathrm{M}$ any factors have contributed to the changing epidemiology of sexually transmitted diseases (STDs) in the past decade. Changes in sexual practices, improved diagnosis and more effective treatments have dramatically reduced the incidence of chlamydia, gonorrhea and syphilis (1). On the other hand, in many countries the incidence of genital herpes (GH) infections has not declined. In the United States, the number of physician office visits for $\mathrm{GH}$ has increased markedly since 1966 (1). There are likely several reasons why significant declines have not been observed: the period of infectivity may extend over many years, GH may be less effectively prevented by condom use, diagnosis of subclinical infections is technically difficult, and no curative treatments are available. Many patients have numerous asymptomatic recurrences and are unable to identify periods of increased infectivity.

There is evidence that the relative prevalence of herpes simplex virus type 1 (HSV-1) and HSV-2 genital infections may be changing. Recent studies from Scandinavia and the United States suggest that HSV-1 infections are increasingly prevalent (2-5). We reviewed the results of genital cultures performed at our hospital over a 30 -month period to determine whether this is also the case in Nova Scotia.

\section{MATERIALS AND METHOD}

The laboratory at the Queen Elizabeth II Health Sciences Centre provides the only virus culture testing in Nova Scotia. The number of cultures, the site, the patient's age and sex, and the culture results were abstracted from the authors' laboratory information system. Only those cultures performed on patients older than 16 years of age where the age and sex were stated on the requisition are included in the analysis. Testing was performed between April 1998 and December 2001. The patient population consisted primarily of patients seen in the offices of physicians practising in the community.

\begin{abstract}
Tissue culture
A549 cells (ATCC CCL-185), a human lung carcinoma cell line, were grown at $37^{\circ} \mathrm{C}$ in RPMI 1640 medium (Gibco Laboratories, USA) supplemented with $10 \%$ heat-inactivated fetal bovine serum, $100 \mathrm{U} / \mathrm{mL}$ of penicillin and $50 \mathrm{U} / \mathrm{mL}$ of streptomycin. Cell monolayers were prepared in conventional culture tubes. When the monolayers were reaching $75 \%$ confluence, usually in $24 \mathrm{~h}$, the growth medium in each culture was replaced with $1 \mathrm{~mL}$ of RPMI 1640 medium supplemented with $2 \%$ fetal bovine serum, $50 \mathrm{U} / \mathrm{mL}$ of ampicillin, $12.5 \mathrm{U} / \mathrm{mL}$ of netilmycin and $5 \mathrm{U} / \mathrm{mL}$ of amphotericin B (maintenance medium).
\end{abstract}

Departments of Pathology, Medicine, and Microbiology and Immunology, Dalhousie University and the Queen Elizabeth II Health Sciences Centre, Halifax, Nova Scotia

Correspondence: Dr K Forward, Division of Microbiology, Queen Elizabeth II Health Sciences Centre, 5788 Universitiy Avenue, Halifax,

Nova Scotia B3H 1V8. Telephone 902-473-4109, fax 902-473-4432, e-mail kevin.forward@cdha.nshealth.ca

Received for publication June 20, 2002. Accepted November 1, 2002 
Virus culture and idenfication

Genital swab specimens taken with the Micro Collection and Transport System (NCS Diagnostics, Etobicoke) were submitted for culture. An aliquot $(0.25 \mathrm{~mL})$ of the specimen in viral transport medium was used to inoculate two A549 monolayers. The cultures were kept at $37^{\circ} \mathrm{C}$ and examined daily for seven days or until $50 \%$ of the monolayer exhibited cytopathic effect. The cultures were then harvested for typing by immunofluorescence with the MicroTrak HSV-1/HSV-2 Culture Identification/Typing Test (Trinity Biotech plc, Ireland). Cultures without cytopathic effect were reported as negative after seven days.

\section{RESULTS}

Over the 30-month period between April 1998 and December 2001, 6529 genital swabs were submitted to the author's laboratory for HSV isolation (Table 1 ). The patient's sex was omitted on 36 requisitions and the age was not indicated on 112 . In total, $2258(34.6 \%)$ swabs were positive. Twelve hundred thirteen $(53.7 \%)$ swabs were HSV-1 isolates. HSV-1 was recovered more often than HSV-2 in specimens from women (1041 of 1790 [58.2\%]). In specimens from women younger than 31 years of age, 780 of 1103 (70.8\%) isolates were HSV-1. Of positive cultures from men of the same age, 99 of 220 (45\%) were HSV-1 isolates.

The percentage of positive genital cultures from which HSV1 was isolated is shown in Table 1 . The proportion of isolates from women that were HSV-1 declined from $73.7 \%$ in those between the ages of 16 and 20 years to $4.5 \%$ in those over the age of 60 years. There was a similar but less dramatic decline in specimens from men, where the relative proportion of HSV-1 isolates declined from $53.8 \%$ in those between the ages of 16 and 20 years to $20.0 \%$ in those older than 60 years of age.

\section{DISCUSSION}

We found that HSV-1 is the predominant isolate from genital specimens submitted in Nova Scotia. Others have also reported a relative increase in HSV-1 isolation rates. In a review of cultures submitted to a Kentucky virology laboratory, Ribes et al (4) noted a trend of increasing HSV-1 rates in both men and women. Between 1994 and 1999, the proportion of genital cultures positive for HSV-1 rose from approximately $27 \%$ to $45 \%$. Lowhagen et al (6) isolated 97 strains of HSV from patients presenting to STD clinics in Sweden between 1995 and 1999. Forty-four per cent were due to HSV-1. When they examined the most recent seroconversions in patients with $\mathrm{GH}, 64 \%$ were due to HSV-1 infections.

Nilsen and Myrmel (2) studied women presenting to an STD clinic in Bergen, Norway. They found that up to $90 \%$ of younger women with primary or initial GH disease had HSV-1 infections. Vyse et al (7) showed that HSV-1 seroprevalence in 10- to 14-year-olds in the United Kingdom declined between 1987 and 1995. They found that HSV-1 seroprevalence increased in individuals between 15 and 24 years of age, suggesting HSV-1 transmission in adolescence and young adulthood may be due to sexual transmission (7). Fifty-four per cent of women between the ages of 25 and 30 years had HSV-1 antibodies. They concluded that a significant proportion of the HSV-1 seropositivity was due to genital infection and that HSV-1 was the predominant cause of $\mathrm{GH}$ in the United Kingdom.

GH simplex infections continue to cause considerable physical and psychological morbidity, even as other STDs such as chlamydia and gonorrheal infections decline. It is believed that the majority of infections are transmitted from asymptomatic people (8-11). The high prevalence of $\mathrm{GH}$ infections, the long period of infectivity, viral shedding without symptoms and incomplete protection with condom use contribute to its continued spread $(12,13)$. In addition, transmission may occur by oral-genital spread as well as by the genital-genital route. HSV-1 is commonly present in the oral cavities of asymptomatic individuals (14-16). Earlier studies suggested that between $10 \%$ and $30 \%$ of GH infections were due to HSV-1 (17). In a study by Langenberg et al (18), the overall rate of HSV-2 infection was 5.1 cases per 100 person-years. The rate of new HSV-1 infections averaged 1.6 cases per 100 patient years. However, only one-third of these cases were proven to be genital infections. It is thought that the majority of these cases were acquired as a result of oral-genital spread; however,

TABLE 1

Summary of the results of genital source herpes simplex virus (HSV) cultures submitted to the Queen Elizabeth II Health Sciences Centre between April 1998 and December 2001

\begin{tabular}{|c|c|c|c|c|c|c|c|c|c|c|c|}
\hline & & & & & anges ( & & & & & & \\
\hline & $16-20$ & $21-25$ & $26-30$ & $31-35$ & $36-40$ & $41-45$ & $46-50$ & $51-55$ & $56-60$ & $>60$ & Total \\
\hline Women & & & & & & & & & & & \\
\hline HSV-1 & 309 & 321 & 150 & 99 & 87 & 39 & 15 & 15 & 4 & 2 & 1088 \\
\hline HSV-2 & 110 & 165 & 48 & 125 & 88 & 71 & 43 & 34 & 23 & 42 & 766 \\
\hline Cultures negative & 508 & 767 & 526 & 393 & 365 & 251 & 157 & 114 & 51 & 123 & 3433 \\
\hline $\begin{array}{l}\text { Percentage of positive cultures } \\
\text { yielding HSV-1 }\end{array}$ & $73.7 \%$ & $66.0 \%$ & $75.8 \%$ & $44.2 \%$ & $49.7 \%$ & $35.5 \%$ & $25.9 \%$ & $30.6 \%$ & $14.8 \%$ & $4.5 \%$ & 5287 \\
\hline Men & & & & & & & & & & & \\
\hline HSV-1 & 21 & 50 & 28 & 20 & 26 & 10 & 4 & 6 & 1 & 6 & 17 \\
\hline HSV-2 & 18 & 48 & 55 & 42 & 37 & 29 & 15 & 21 & 7 & 24 & 305 \\
\hline Cultures negative & 118 & 232 & 129 & 119 & 111 & 88 & 59 & 52 & 31 & 77 & 1083 \\
\hline $\begin{array}{l}\text { Percent of positive cultures } \\
\text { yielding HSV-1 }\end{array}$ & $53.8 \%$ & $51.0 \%$ & $33.7 \%$ & $32.3 \%$ & $41.3 \%$ & $25.6 \%$ & $21.1 \%$ & $22.2 \%$ & $12.5 \%$ & $20.0 \%$ & 1562 \\
\hline Total & & & & & & & & & & & \\
\hline Positive cultures & 459 & 585 & 281 & 286 & 238 & 149 & 77 & 76 & 35 & 74 & 2343 \\
\hline Negative cultures & 626 & 1002 & 658 & 514 & 478 & 339 & 216 & 167 & 83 & 200 & 4542 \\
\hline Cultures submitted & 1085 & 1587 & 939 & 800 & 716 & 488 & 293 & 243 & 118 & 274 & 6885 \\
\hline
\end{tabular}


the exact proportion of spread by different forms of sexual contact had not been fully elucidated. Clearly, some HSV-1 infections may be acquired from vaginal intercourse.

Unfortunately, we do not have access to information on the relative frequency of isolation of HSV-1 and HSV-2 from genital specimens before April 1998, and we do not have data on whether the cultures were from primary or recurrent infections. As a result, it is not possible to say how closely our numbers reflect the relative proportion for incident infections, although we were unable to exclude duplicate results from our evaluation because HSV-2 infections recur more often and, if anything, this would bias observations toward null. Assuming that our numbers represent a fair surrogate marker of relative incidence, how are the differences explained? In some settings, the frequency of oral HSV-1 infections in childhood may be declining. As a result, many more individuals reach adulthood without specific immunity to HSV-1 and may be more susceptible to infection and more likely to present with a clinically apparent infection $(19,20)$.

Changing sexual practices may be contributing to the shift toward more HSV-1 infections. We do not have information

\section{REFERENCES}

1. Centers for Disease Control and Prevention. Tracking the Hidden Epidemics. Trends in STDs in the United States, 2000. Atlanta: Centers for Disease Control and Prevention, 2000. <http://www.cdc.gov/ nchstp/dstd/Stats_Trends/Trends2000.pdf> (Version current at March 18, 2003).

2. Nilsen $\mathrm{A}$, Myrmel $\mathrm{H}$. Changing trends in genital herpes simplex virus infection in Bergen, Norway. Acta Obstet Gynecol Scand 2000;79:693-6.

3. Wilson P, Cropper L, Sharp I, Fink C. Apparent increase in the prevalence of herpes simplex virus type-1 genital infections among women. Genitourin Med 1994;70:228.

4. Ribes JA, Steele AD, Seabolt JP, Baker DJ. Six-year study of the incidence of herpes in genital and nongenital cultures in a central Kentucky medical center patient population. J Clin Microbiol 2001;39:3321-5.

5. Nageswaran A, Shen RN, Kinghorn GR, Patel R. Apparent increase in the prevalence of herpes simplex virus type-1 genital infections among women. Genitourin Med 1994;70:427.

6. Lowhagen GB, Jansen E, Nordenfelt E, Lycke E. Epidemiology of genital herpes infections in Sweden. Acta Derm Venereol 1990;70:330-4.

7. Vyse AJ, Gay NJ, Slomka MJ, et al. The burden of infection with HSV-1 and HSV-2 in England and Wales: Implications for the changing epidemiology of genital herpes. Sex Transm Infect 2000; 76:183-7.

8. Koelle DM, Benedetti J, Langenberg A, Corey L. Asymptomatic reactivation of herpes simplex virus in women after the first episode of genital herpes. Ann Intern Med 1992;116:433-7.

9. Lafferty WE, Coombs RW, Benedetti J, Critchlow C, Corey L. Recurrences after oral and genital herpes simplex virus infection. Influence of site of infection and viral type. N Engl J Med 1987;316:1444-9.

10. Mertz GJ, Benedetti J, Ashley R, et al. Risk factors for the sexual transmission of genital herpes. Ann Intern Med 1992;116:197-202.

11. Wald A, Zeh J, Selke S, et al. Virologic characteristics of subclinical and symptomatic genital herpes infections. N Engl J Med 1995;333:770-5.

12. Wald A, Langenberg AG, Link K, et al. Effect of condoms on reducing the transmission of herpes simplex virus type- 2 from men to women. JAMA 2001;285:3100-6.

13. Conant MA, DW Spicer, CD Smith. Herpes simplex virus transmission: Condom studies. Sex Transm Dis 1984;11:94-5.

14. Scott DA, WA Coulter, PJ Lamey. Oral shedding of herpes simplex virus type-1: A review. J Oral Pathol Med 1997;26:441-7.

15. Scott DA, Coulter WA, Biagioni PA, O'Neill HO, Lamey PJ. Detection of herpes simplex virus type- 1 shedding in the oral cavity by polymerase chain reaction and enzyme-linked immunosorbent assay at the prodromal stage of recrudescent herpes labialis. J Oral Pathol Med 1997;26:305-9.

16. Spruance SL. Pathogenesis of herpes simplex labialis: Excretion of virus in on the sexual practices of Nova Scotians with GH that may offer insight into our findings. The higher proportion of young women than men who were infected with HSV-1 versus HSV-2 may reflect a greater susceptibility of the female genital tract or a greater propensity to transmit herpes viruses by cunnilingus compared with fellatio. We are unaware of studies that have examined this question. Such studies would be useful to better understand oral-genital transmission between couples.

The predominance of HSV-1 in GH cultures has a number of important implications. The information we give to patients may need to change because the likely mode of acquisition may be different and HSV-1 infections are less likely to recur (21-27). These results also raise questions about the utility of type-specific antibodies to diagnose someone as 'genitally infected'. These findings also make the use of HSV-2 serological population-based studies much less useful for determining the prevalence of $\mathrm{GH}$. Additionally, vaccine development has largely centred around HSV-2 (18,28-31). Our findings suggest that such vaccines may be less valuable unless they also provide excellent protection from HSV-1.

the oral cavity. J Clin Microbiol 1984;19:675-9.

17. Corey L, Adams HG, Brown ZA, Holmes KK. Genital herpes simplex virus infections: Clinical manifestations, course, and complications. Ann Intern Med 1983;98:958-72.

18. Langenberg AG, Corey L, Ashley R L, Leong WP, Straus SE. A prospective study of new infections with herpes simplex virus type- 1 and type-2. Chiron HSV Vaccine Study Group. N Engl J Med 1999;341:1432-8.

19. Gibson JJ, Hornung CA, Alexander GR, Lee FK, Potts WA, Nahmias AJ. A cross-sectional study of herpes simplex virus types- 1 and -2 in college students: Occurrence and determinants of infection. J Infect Dis 1990;162:306-12.

20. Christenson B, Bottiger M, Svensson A, Jeansson S. A 15-year surveillance study of antibodies to herpes simplex virus types -1 and -2 in a cohort of young girls. J Infect 1992;25:147-54.

21. Benedetti J, Corey L, Ashley R. Recurrence rates in genital herpes after symptomatic first-episode infection. Ann Intern Med 1994;121:847-54.

22. Brugha R, Keersmaekers K, Rentonv A, Meheus A. Genital herpes infection: A review. Int J Epidemiol 1997;26:698-709.

23. Fife KH, Schmidt O, Remington M, Corey L. Primary and recurrent concomitant genital infection with herpes simplex virus types -1 and -2 . J Infect Dis 1983;147:163.

24. Adams HG, Benson EA, Alexander ER, Vontver LA, Remington MA, Holmes KK. Genital herpetic infection in men and women: Clinical course and effect of topical application of adenine arabinoside. J Infect Dis 1976;133(Suppl A):151-9.

25. Vontver LA, Reeves WC, Rattray M, et al. Clinical course and diagnosis of genital herpes simplex virus infection and evaluation of topical surfactant therapy. Am J Obstet Gynecol 1979;133:548-54.

26. Kaufman RH, Gardner HL, Rawls WE, Dixon RE, Young RL. Clinical features of herpes genitalis. Cancer Res 1973;33:1446-51.

27. Corey L, Benedetti JK, Critchlow CW, et al. Double-blind controlled trial of topical acyclovir in genital herpes simplex virus infections. Am J Med 1982;73:326-34.

28. Boursnell ME, Entwisle C, Blakeley D, et al. A genetically inactivated herpes simplex virus type-2 (HSV-2) vaccine provides effective protection against primary and recurrent HSV-2 disease. J Infect Dis 1997;175:16-25.

29. Stanberry LR. Herpes. Vaccines for HSV. Dermatol Clin 1998;16:811-6.

30. Stanberry LR, Cunningham AL, Mindel A, et al. Prospects for control of herpes simplex virus disease through immunization. Clin Infect Dis 2000;30:549-66.

31. Pachuk CJ, Arnold R, Herold K, Ciccarelli RB, Higgins TJ. Humoral and cellular immune responses to herpes simplex virus-2 glycoprotein D generated by facilitated DNA immunization of mice. Curr Top Microbiol Immunol 1998;226:79-89. 


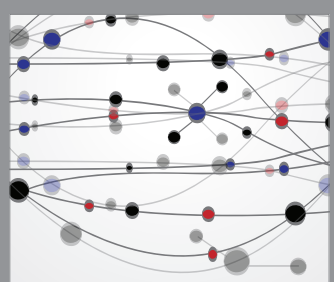

The Scientific World Journal
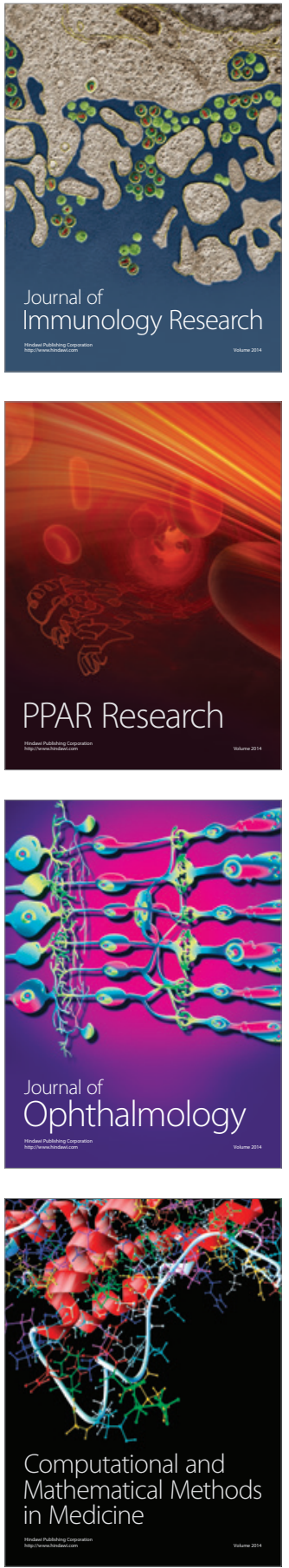

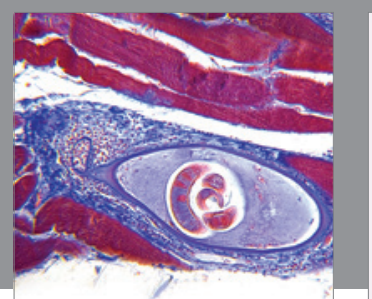

Gastroenterology Research and Practice

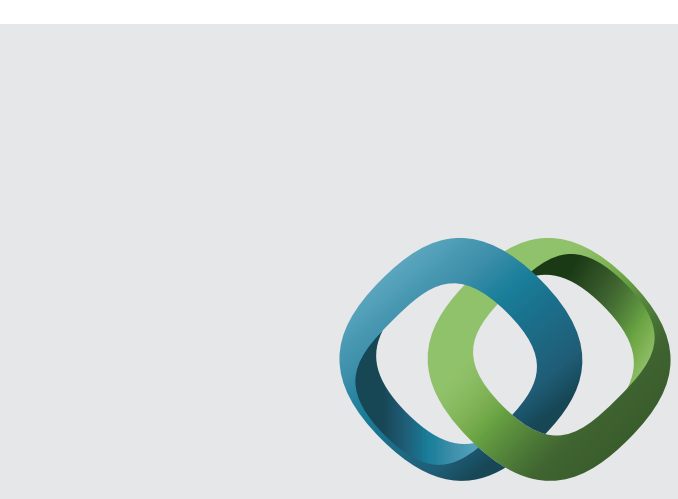

\section{Hindawi}

Submit your manuscripts at

http://www.hindawi.com
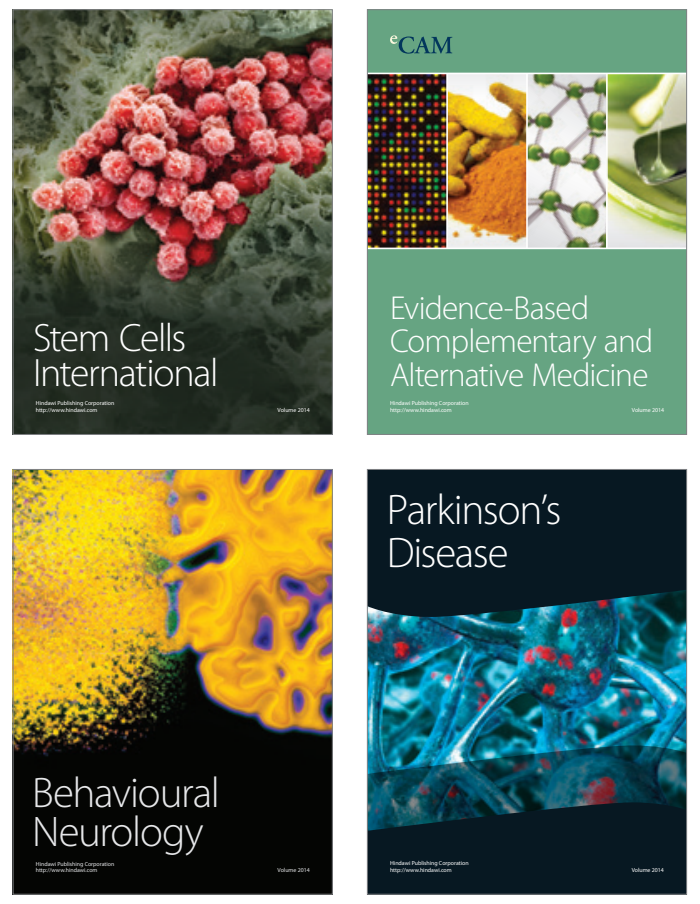
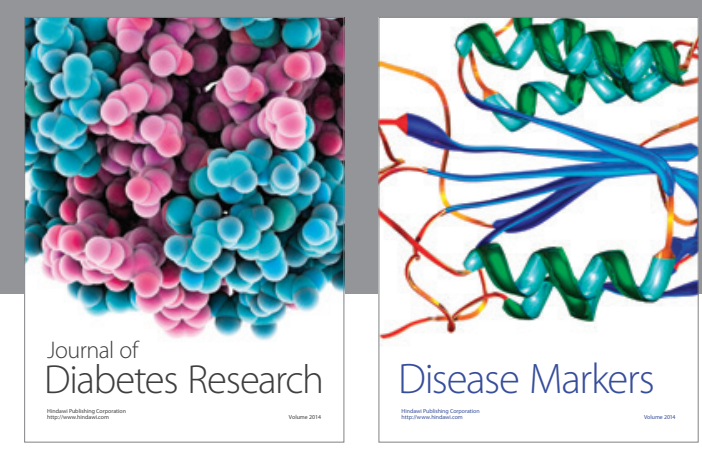

Disease Markers
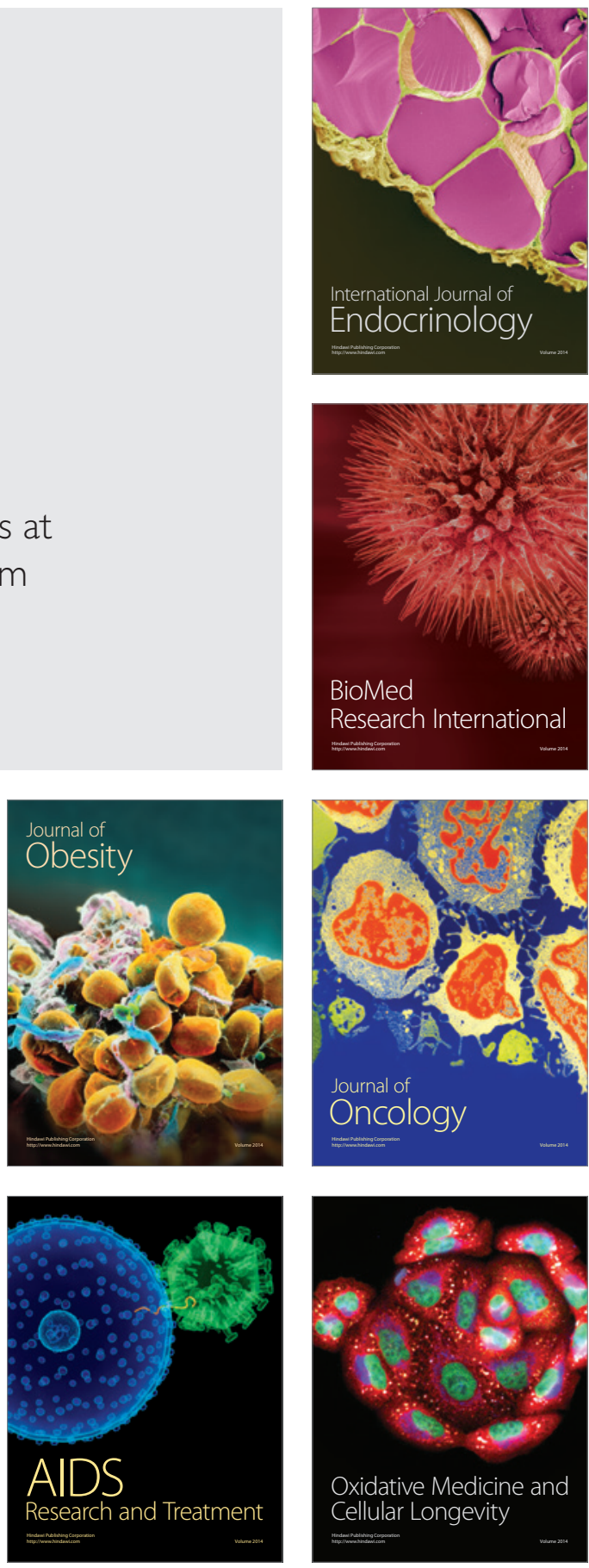